\title{
The Path Choice of the Chinese Communist Party's Theoretical Innovation under the Perspective of Chinese Traditional Culture
}

\author{
Wei Wei ${ }^{1} \&$ Wei Bin $^{2}$ \\ ${ }^{1}$ School of Marxism, Qvfu Normal University, Rizhao, China \\ ${ }^{2}$ Rizhao Polytechnic, Rizhao, China \\ Correspondence: Wei Wei, school of Marxism, Qvfu Normal University, Post Code: 276800, Rizhao, Shandong \\ Province, China. Tel: 86-15953087878. E-mail: 761862532@qq.com
}

\author{
Received: April 13, 2017 \\ Accepted: April 28, $2017 \quad$ Online Published: May 31, 2017 \\ doi:10.5539/ass.v13n6p159 \\ URL: https://doi.org/10.5539/ass.v13n6p159
}

\begin{abstract}
At present, the domestic and the academic circles have questioned the status and value of the traditional culture which is represented by Confucianism. Facing the traditional culture dissemination heat of the state, how to treat correctly its value and significance, how to clarify the relationship between the traditional culture and the party's theoretical innovation, how to rationally deal with the traditional culture of the premise under exploration in the path of the theoretical innovation of the Communist Party of China, this is the original intention of this paper.
\end{abstract}

Keywords: Traditional culture, Marx, Theoretical innovation

The traditional Chinese culture represented by Confucianism is the unique spiritual symbol of the Chinese nation, which is the foundation of our firm foothold in the world culture. Under the background of this kind of culture, the Chinese Communist Party, taking Marx as the guiding ideology, pays special attention to the relationship between the theoretical innovation of the party and the traditional culture. How to treat the traditional culture with scientific attitude and apply it to the party's theoretical innovation is a question worth considering.

\section{The Theoretical Innovation of the Communist Party of China Must Unswervingly Adhere to the Marx Doctrine}

The Marx doctrine is a scientific world outlook and methodology, is a powerful ideological weapon and transform the world, the Communist Party of China since the date of birth will be regarded as the guiding ideology of the Marx doctrine, which has never been shaken. "No one kind of philosophy or theory in modern history of the world left so much as the Marx doctrine: it China occupy the dominant position in Russia and has been for decades, influence and determine and control the billions of people and several generations of fate fundamentally." [Li Zehou, the history of thought Chinese (2) [M]. Hefei: Anhui literature and Art Publishing House, 1999965 pages. From the perspective of history, Marx pointed the way for the liberation of the proletariat and human, is a powerful theoretical weapon and action guide Chinese Communist Party China led the people in revolution, construction and reform. From a realistic point of view, Marx doctrine plays a fundamental role in the overall development of the party and the country. On the one hand, the Marx doctrine is the foundation of basic party country, is the guide for development of socialism; on the other hand, the Marx doctrine as the guiding ideology is a tool for social development firm ideology of defense, resist various ideological impact from inside and outside the party, both at home and abroad, to provide protection for the development of the party and the country's domestic industry. That is to say, the guiding position of Marx's theory runs through the party's theoretical innovation.

The great power of Marx's doctrine of Marxism lies in the fact that it is connected with the concrete revolutionary practice of each country. For Chinese Communist Party members, it is necessary to learn to apply Marx's theory of Marxism in China's specific environment." With the development of practice, the development of Marx's theory is the character of the Chinese Communist Party, the Communist Party of China in the treatment of the attitude of Marx, always adhere to the basic theory of Marxism and China's reality combined with the theory of the attitude of the Communist Party of China, the Communist Party of China in the treatment of the doctrine of Marxism, the attitude of the Communist Party of China and the basic theory of Marxism. The process of theoretical innovation of the Communist Party of China is a historical process of Marx's theory. The 
party's theory innovation process with the development of the problems in the practice, the Communist Party continued to break through the previous ideological barriers and restrictions, to integrate theory with practice, emancipating the mind and seeking truth from facts, discard dogmatism and bookishness and empiricism, on the basis of inheriting, enriching and developing the basic theory of Marx doctrine.

The theoretical innovation of the Communist Party of China must adhere to the premise of Marx. Without revolutionary theory, there would be no revolutionary movement." [Lenin, Lenin Anthology (second volumes) [M]. Beijing: People's publishing house, 1995282 pages. Theoretical innovation is to solve the specific problems encountered in the construction of the party. The Marx doctrine has laid the scientific world outlook and methodology foundation for the party's theoretical innovation, and has pointed out the correct direction for the party's theoretical innovation. In this sense, party theory innovation process, it is a adhere to the Marx doctrine as the guiding ideology, historical process and constantly with new ideas and methods to solve practical problems; it is a adhere to Marx theory as the guiding ideology to unite the party, unite the party's fighting capacity, highlighting the advanced of the party, promote the party's history of the development process. Any innovation activities of the party, must be based on the premise of Marx doctrine, can not be shaken at any time.

\section{Traditional Culture Is the Foundation and Motivation of the Communist Party of China to Carry Out Theoretical Innovation}

The traditional Chinese culture represented by Confucianism is the unique spiritual symbol of the Chinese nation, which is the foundation of our firm foothold in the world culture. General secretary Xi Jinping at the Central Party School 80 anniversary speech pointed out: "the Chinese traditional culture is broad and profound, study and grasp the essence of them, to establish a correct world outlook, outlook on life and values are very useful. History can see the success, with gains and losses, rise and fall; poetry can fly, high, witty; ethics can know the sense of honor, honor, know right from wrong." Chinese culture has a long history, the accumulation of the deepest spiritual pursuit of the Chinese nation, representing the unique spiritual identity of the Chinese nation, for the Chinese nation to grow, develop and grow to provide a rich nourishment. The traditional thought, social commitment to support unremitting self-improvement of the Chinese nation, life and growth in nature today is still passing the torch, we promote the reform and opening up and socialist modernization and powerful spiritual force.

In the different historical periods of revolution, construction and reform, the Communist Party of China took the traditional culture as the cultural foundation and the important resource in the theory innovation. Chinese traditional culture, which has the unique value of traditional culture and the spirit of the times, can be used and developed in the party's theoretical innovation process.

In October 1938, Mao Zedong made in the sixth Plenary Session of the 6th CPC Central Committee on the party's political report "on the new stage", proposed "the Marx doctrine and the specific characteristics of our country must be combined to achieve through a definite national form." This is Mao Zedong's scientific judgment on the doctrine of Marx and the realistic environment, and it is an important consideration for the Sinicization of Marxism in the process of the localization of Marxism in china. At the same time, Mao Zedong made clear that the Communist Party China attitude to Chinese traditional culture: "we learn historical heritage, with the method of Marx's critically summarize, is another of our tasks. Our nation has thousands of years of history, has its characteristics, has many of its precious goods. For these, we are primary school students. Today's China is a development of the history of China; we are Marx's historicism, we should not cut off the history. From Confucius to Sun Zhongshan, we should make a summary of this precious heritage." [Mao Zedong, Mao Zedong Anthology (second volumes) [M]. Beijing: People's publishing house, 1995533-534.

Mao Zedong's personal traditional culture is very deep, very familiar with the elements of Chinese culture and the language form. The leader of the traditional culture innate and objective understanding, the main founder of Mao Zedong thought, Mao Zedong, in combination with the theoretical innovation of the traditional culture and the party has made a significant contribution.

In the traditional culture of the "practical" influence he has always been to the country and the nation as their career goal; "he put Marx's influence all-embracing" and Chinese traditional culture can convince people with perfect China; "political uprising" he found fundamental - armed revolution means of Chinese revolution; "seeking truth from facts" affect his use of traditional culture Chinese philosophical achievements of the essence of the party's ideological line.

The most important thing is that Mao Zedong's attitude towards traditional culture, from the cultural policy of the Chinese revolution, was pushed to the methodological level of all the party's work. "Letting a hundred flowers bloom" is a way of developing art. Well, All flowers bloom together. policy is not the contention of a 
hundred schools of thought method, but the scientific and artistic development and extension, it is also a good method we all work performed. This method can make us less mistakes."

The historical experience of the innovation of traditional culture and the party told us that the party's theory is a process of innovation, adhere to the Marx doctrine as the fundamental principle and development of the Marx doctrine of unity, is a process of using Marx's attention to basic theory and Chinese revolution, construction and reform of the combination, is a combination of Marx doctrine Chinese and excellent traditional culture and unity.

\section{The Theoretical Innovation of the Communist Party of China Need to Establish a Scientific Concept of Traditional Culture}

General view of theoretical innovation of the Communist Party of Chinese, refers to the comprehensive innovation elements involved in the process of the construction of the party, is a complex process, including many factors; the narrow sense, the party's theoretical innovation refers to innovation on the party's guiding ideology, basic theory, the purpose of Gen Benzong. The theoretical innovation of the party is the fundamental guarantee for its sustainable and healthy development. In the new era, the Communist Party of China must uphold the fine tradition of the use of excellent traditional culture, and constantly develop the party's own theoretical system, in order to promote the great cause of Sinicization of Marxism, Marx. How to establish the scientific concept of traditional culture is the premise of the path choice of the party's theoretical innovation in the traditional culture. So, how to establish a scientific concept of traditional culture?

\subsection{The Attitude towards Traditional Culture, Should Return to Normal, Out of the Hot State}

No matter from the general law of the development of culture or the special law of the evolution of Chinese traditional culture, the theoretical innovation of the Communist Party of China can not leave the existing cultural tradition and cultural resources. The Communist Party of Chinese in attitude towards traditional culture, can not abandon the traditional culture as the fertile soil to nourish every Chinese people, the traditional culture as the theoretical innovation of the party the valuable resources and cultural basis, with "methodology All flowers bloom together., treat the value of contention of a hundred schools of thought" and the significance of the traditional culture.

Historical materialism thinks that culture is an important part of the construction of socialism China characteristics, not only can reflect the level of economic development, also on the whole social economic and political development is counterproductive, how to deal with culture, is related to the social development in the construction of the party's important issues.

The party's theoretical innovation process can not be avoided. In the face of domestic and international, the party and outside of the traditional Chinese culture of the hot situation, to maintain a calm and rational understanding, to use Marx's position and views on the specific content of traditional culture. In dealing with the attitude of traditional culture, it should be returned to normal, out of the hot state.

\subsection{The Content of Traditional Culture Should Be Broken Away from the Whole Treatment, Absorb the Essence, Eliminate the Dross}

The traditional culture is a neutral concept, which not only contains 5000 years of civilization brings civilization heritage, but also contains a heinous for humanity. The traditional culture emerged and developed in the ancient Chinese Society for thousands of years. [a youth, the theoretical system of socialism with China characteristics of the [D]. research foundation of traditional culture of Shandong University, page 2012207. Both the excellent spirit of unremitting self-improvement, seeking truth from facts, and the feudal autocratic monarch, unfair residue harm to the most complex, however, is the essence and the dross mixed and intertwined, it is difficult to let the body for later generations we sort of clear and clear discrimination.

In the content of the treatment of traditional culture, should be in a systematic and dialectical point of view, what is what is the essence of discrimination should be based on the practice of socialist dross, China characteristics, in order to identify the development of the Chinese nation. The development of the socialist economy is conducive to the promotion of traditional culture is the excellent traditional culture, can enhance people's moral qualities of traditional culture is the outstanding traditional culture, to promote social civilization and harmonious culture is the excellent traditional culture, can help to promote the socialist core values of the traditional culture is the excellent traditional culture. Any form of grandstanding, in content, contrary to the guiding ideology of Marx's traditional culture, is the traditional culture of the dross, in the party's theoretical innovation process, is the need to be removed. 


\subsection{It's good at carrying forward the excellent traditional culture and the development of the reality of cultural unity}

The wheel of history and reality of the flood has pushed us to have to face the future ", the Communist Party of Chinese on the road of the theory innovation, how to solve the problem of traditional culture and modernization, is must face the link. "Some of the same themes have been brought back in almost a few years, and they are always criticizing the tradition, rebuilding the tradition, criticizing the tradition and rebuilding the tradition. The result is, in terms of how to inherit the excellent traditional culture, we have little time to hesitate. "[Guo Jianning, inheriting excellent traditional culture development China advanced culture [N]. Beijing: People's daily, 2011,11/4.].

Between traditional culture and modernization seems to produce a misunderstanding, that is, the traditional culture in the past, the party's theory innovation process has been down even erased, and ignore the basic role in the process of cultural modernization. In the process of theoretical innovation of the Communist Party of China, how to make good use of the traditional culture as the foundation, and excavate the traditional culture theory which is suitable for modernization, is an important part of the theoretical innovation in the future.

\subsection{In the development of inheritance, in the development of inheritance.}

The theoretical innovation of the party is the proper meaning of Marx 's Sinicization of Marxism. In the problem of the relationship between traditional culture and Marx" s theory, we should insist on the development in the inheritance and inherit in the development. The Communist Party of China is not only the faithful inheritor and the pioneer of Chinese excellent traditional culture, but also an active advocator and developer of Chinese advanced culture". The Communist Party is China shouldering the excellent traditional culture used in the development of the reality, but also shoulder the application in practice of excellent traditional culture inheriting, two kinds of responsibility are two aspects of the same process, or that they are unified in the China communist theory innovation process. Therefore, the party's theoretical innovation must adhere to the development of Marx in the process of inheriting the excellent traditional culture, and continue to develop excellent traditional culture in the process of the development of Marxism.

\section{The party's theoretical innovation needs to be proficient in the traditional culture of Marx theory team}

Different from the development of the nature, the innovation of the theory must have the participation of the main body, that is to say, the person who can be regarded as the main body of cognition can make the theory innovation carry on. On the theoretical innovation of the Communist Party of Chinese, the subject of theoretical innovation, is the Marx doctrine theory workers with profound accomplishment, standing in the angle of traditional culture, to dig the object of innovation can in the traditional culture, with Marx's standpoints and methods to treat and understanding of traditional culture. It is impossible for the traditional culture to carry on the innovation of the theoretical level, and only the participation of the main body is the possibility of the theoretical innovation.

To understand the traditional culture itself is far from enough, the party's theoretical workers also need to develop awareness of traditional culture. The traditional culture as a treasure of national culture is the most precious cultural symbol for the Chinese nation, already deeply the sons and daughters of the bone marrow into all the children of the Yellow Emperor soul, but the traditional opposite modern, cherished tradition does not mean you can ignore the modern. The reason for the innovation of the theory, is the inevitable result of some theories are no longer able to effectively guide the practice, no longer able to play the guiding role of theory in the face of the new situation, this theory must be innovative, otherwise it will lose its meaning of existence.

The theoretical innovation of the party must cultivate a strong Marx, but also need to be proficient in Chinese traditional culture. Marx's theory of the Communist Party of China team, the need for both proficient in the traditional Chinese culture of Marxism and the talent of the people of Marx.

Marx doctrine is the premise of all the work of the party, is the party's revolution, construction and reform of the fundamental guiding principles, can not be shaken at any time. If there is no understanding of the Marx doctrine as the basis and premise of theory workers, would not be possible for real and practical problems in the scientific and dialectical understanding and analysis, can not be used to guide the practice of the theory can be. In addition, the party's theoretical workers must be based on the reality of China, relying on the traditional culture of the Chinese nation to carry out theoretical innovation. The Marx doctrine is never changeless dogmatic, if you can not solve the problems in the practice, the theory is just words on paper, not with practical guidance, the necessary theory will not exist. Chinese traditional culture is a theory of the party workers must face the actual China, must be carried out theoretical innovation in natural resources, according to need to practice, fully 
understanding and innovation of traditional culture, is an important part of the party's theory innovation.

\section{References}

Guo Jianning, (2011, November 4). Inheriting the excellent traditional culture and developing the advanced culture of China. People's Daily.

Lenin. (1995). Selected works of Lenin (2nd volume). Beijing: People's publishing house.

Li Zehou. (1999). The History of Chinese thought . Hefei: Anhui literature and Art Publishing House.

Mao Zedong. (1995). Selected works of Mao Zedong (2nd volume). Beijing: People's publishing house.

Xu Qing. (2012). The study of the traditional cultural foundation of the theoretical system of socialism with Chinese characteristics. Shandong University, Jinan, China.

\section{Copyrights}

Copyright for this article is retained by the author(s), with first publication rights granted to the journal.

This is an open-access article distributed under the terms and conditions of the Creative Commons Attribution license (http://creativecommons.org/licenses/by/4.0/). 